\title{
ÁLLÁSKERESÉSI TRENDEK HEVES MEGYE MUNKAVÁLLALÓI KÖRÉBEN
}

\author{
Bata Miléna - Benedek Andrea
}

\section{Összefoglalás}

Elméleti háttér: Az elmúlt évtizedekben, különösen a 2000-es évek óta, a HR-innováció és az azokhoz kapcsolódó trendek a globális üzleti világ fontos kérdéseivé váltak. A témát sok megközelitésböl vizsgálták már, mégis - állandó változása miatt - a mai napig a tudományos élet különleges és érdeklödésre számot tartó területe maradt. Jelen kutatás az álláskeresök munkahelyválasztási döntést befolyásoló tényezöit vizsgálja.

Kutatási cél: A kutatás elsödleges célja, hogy feltárja a munkakeresök álláskeresési preferenciáit, a választott álláskeresési platformokat. Továbbá célja volt, hogy megismerje, mely tényezök befolyásolják munkahelyválasztási döntéseiket.

Anyag és módszer: A primer kutatás lefolytatására Magyarországon élö álláskeresök körében 2019-ben került sor. A kutatás adatbázisát a Heves megyében élö munkaképes korosztály kérdöives lekérdezése képezte.

Kutatási eredmények: Az empirikus kutatás fontos eredménye, hogy a munkahelyválasztási döntését befolyásoló tényezők alapján (egyéni készségek, képességek; egyéni készségeket vállalati oldalról támogató és külsö környezeti tényezök szerint) sikerült három egymástól jól elhatárolható, releváns álláskeresöi csoportot azonositani, melyek a következók voltak: vállalati támogatást fontosnak tartó csoport, a semleges és az egyéni készségek önálló fejlesztését fontosnak tartó szegmens. Ezek az álláskeresöi szegmensek - a munkahelyválasztási döntést befolyásoló tényezöket tekintve - karakterisztikusan eltérnek egymástól, igy a jövöbeli lehetöségek szempontjából ezek a szegmensek jól pozícionálható és jól megcélozható csoportokat képeztek.

Kulcsszavak: álláskeresők, személyi szolgáltatóltanácsadó, humán eröforrás, munkavállalói döntések

JEL: D83

DOI: 10.33032/acr.2020.10.1.5 


\title{
TRENDS IN JOB SEARCH AMONG THE JOB-SEEKERS IN HEVES COUNTY
}

\begin{abstract}
Background. In the last few decades, especially since the 2000s, the HR innovation and new trend at the field of human resource have become important issues. This field has been studied from several different angles, however, because of its constant change it is still an area of interest.

The present study focuses on the factors influencing job choice decision from the job-seeker point of view.

Research aims. The primary research examines the job search preferences of job-seekers and the chosen job search platforms. Other hand the research was to find out the factors influencing the job choice decision of job-seekers.

Methodology. A primary research was carried out among job-seekers in Hungary in 2019. The target population comprised the working age population in Heves county This research focuses on presenting the results and findings of the quantitative analysis based on the responses given by the jobseekers.

Key findings. An important result of the empiric research is that regarding the factors influencing their job choice decision three different job-seeker groups were identified. These are the followings: corporate support emphasized segment, neutral and self-development of the individual skill emphasized segment. The mentioned groups can be clearly distinguished from each other based on their job choice decision, hence the groups can be very well positioned and targeted.
\end{abstract}

Keywords: job-seeker, personal adviser, human resource, job-choice decision 


\section{Bevezetés}

A technológiai és gazdasági fejlődés gyorsulása mindannyiunkat kihívások elé állít nap mint nap mind magánemberként, mind munkavállalóként. A legnagyobb kihívást, illetve egzisztenciánk alapját azonban mégis a munkánk jelenti, hiszen az elvégzett munkáért cserébe kapott jövedelemből tartjuk el magunkat és családunkat. A multinacionális vállalatok térnyerésével felértékelődött a személyzeti szolgáltató cégek jelenléte a munkaerőpiacon, illetve segítségükkel mára az álláskeresés is sokrétủbbé, egyszerübbé vált. Amennyiben kapcsolatba kerülünk egy szolgáltatóval, egyszerre akár több pozíciót is megismerhetünk, illetve képet kaphatunk a piaci helyzetről, tanácsot kérhetünk álláskeresésünket illetően. Ezen cégek sikere nem csupán attól függ, hogy milyen gyorsan tudnak reagálni a piaci környezet változásaira, hanem hogy mennyire kapcsolhatók az egyes tevékenységek, mennyire professzionális az állomány, illetve hogy a szolgáltatások köré felépített branddel hatékonyan megszólíthatóak-e a potenciális munkavállalók. Ám a személyzeti tanácsadók szerepe is háttérbe szorulhat a jövőben, mivel a jelenlegi nemzetközi prognózisok azt mutatják, hogy a mobilos platformok előtérbe kerültek. A munkaerőpiaci trendeket támasztja alá a Deloitte által 2018-ban végzett kutatás is, mely szerint az álláskeresés ma már elsődlegesen a virtuális platformokon megy végbe. A digitalizációnak köszönhetően a tanácsadó cégek saját karrieroldallal is rendelkeznek, Majó (2007) megközelítésében ez lehetőséget ad a személyre szabott állásajánlatok nyújtására, mely - mivel kifejezetten személyes - fontos szerepet jelent a bizalom, ezáltal a jelöltekkel történő hosszú távú együttműködés kialakulásában. Davis (2004) szerint éppen a végbemenő digitalizáció miatt bizonyos HR-funkciók a jövőben meg is fognak szünni, a kérdés csupán az, hogy mikor?

A kutatási problémát az jelentette, hogy hogyan hat a digitalizáció az álláskeresési preferenciákra a munkaerőpiacon, ez alapján a következő cél és hipotézis került megfogalmazásra:

C1: A válaszadók álláskeresési preferenciáinak vizsgálata.

H1: Az álláskeresők elsősorban az online platformokat részesítik előnyben álláskeresésük során.

C2: A munkavállalók munkahelyválasztási döntését befolyásoló tényezőinek vizsgálata.

H1: Az álláskeresők számára fontosak az egyéni képességeiket támogató vállalati tényezők. 


\section{Anyag és módszer}

A primer kutatás során kvantitatív jellegű, kérdőíves megkérdezésre került sor a Heves megyében élő munkaképes korosztály körében. A lekérdezés online és a személyes megkérdezés módszerével, 2019-ben történt. A kutatás adatbázisát képező kérdőívet 205 fó válaszai képezték.

\section{Eredmények}

\section{Demográfia}

A kitöltési hajlandóságot tekintve a nők aktívabbak voltak (143 fó), a férfiak a kitöltők egyharmadát (62 fó) tették ki.

A válaszadók megoszlását gyermekeik száma szerint is megfigyeltük: 51,7\%-uk gyermektelen, 18\%-uknak egy, 24,3\%-uknak kettő gyermeke van. A megkérdezettek csupán 6\%-ának (12 fó) van 3 vagy annál több gyermeke.

A válaszadókat családi állapotuk szerint hét csoportra osztottuk, és lehetőséget adtunk arra is, hogy ezen kérdés tekintetében ne kelljen megjelölniük választ. 38\%uk házas, 20,9\%-uk párkapcsolatban, 17\%-uk pedig élettársi kapcsolatban él. A válaszadók kevesebb mint negyede él házasként külön háztartásban, egyedülállóként, elváltként vagy özvegyként.

A válaszadók 62,9\%-a föiskolát vagy egyetemet végzett, 20,4\%-a középiskolai érettségit szerzett, 16,7\%-uk szakiskolát/szakmunkásképzőt végzett. 1 fó általános iskolai végzettséggel rendelkezik. Jelentős részük (46,8\%) nettó jövedelme 200-400 ezer forint között mozog, 25,8\%-uk 100-200 ezer, 15,1\%-uk 100 ezer forint alatti nettó jövedelmet szerez havonta.

A kérdőívkitöltők 79,5\%-a szellemi munkát végez, de majd negyedük fizikai munkából él.

\section{Álláskeresési preferenciák}

\section{Álláskeresési platformok}

Az álláskeresési preferenciák vizsgálata során az első kutatási cél az volt, hogy feltárjuk, milyen platformokat részesítenek előnyben ma az álláskeresők, a kutatás a következő eredményt hozta.

A megkérdezettek legtöbbször az online platformokat (profession.hu, cvonline. hu), az állásportálokat használják keresésük során. A minta 75\%-a az álláskeresés ezen formáját részesíti előnyben. 
Ezzel $H 1$ hipotézis igazolást nyert, mely szerint: Az álláskeresök elsösorban az online platformokat részesitik elönyben álláskeresésük során.

A második legnépszerübb álláskeresési mód azonban még mindig a személyes ajánlás, a válaszadók mintegy 36\%-a ilyen módon keres állást. Ezt követi egy újabb online felület, a Facebook, illetve a LinkedIn.

Látható, hogy bár napjainkban a trendek azt mutatják, hogy a mobilos platformok használata egyre népszerübb, Heves megyében még mindig jelentős a személyes ajánlás útján történő keresés is (1. ábra). Míg az állásportálok használata elsősorban kényelmi szempontok miatt örvend népszerüségnek - vagyis azért, mert a mobilalkalmazás bárhol és bármikor elérhető felület az álláskeresők számára, addig a személyes ajánlás alapja egyfajta bizalmi kapcsolat. Ha megbízunk valakiben, valószínü, hogy elfogadjuk az ajánlott vállalatról kapott információkat, és szívesen pályázunk egy-egy nyitott pozícióra. Az 'employer branding', azaz a munkáltatói márkaépités szempontjából ez egyáltalán nem elhanyagolható tényező, hiszen amíg a személyes ajánlásnak nagy szerepe van az álláskeresésben, addig mind a munkavállaló, mind pedig a munkáltató számára jól használható költség- és időtakarékos eszköz lehet a toborzásra azáltal, hogy a jelöltek tulajdonképpen „házhoz jönnek”.

Munkavállalói oldalról pedig különösen a kis- és középvállalatok körében a személyes ajánlás útján történő álláskeresési kezdeményezés növeli a pályázó esélyeit.

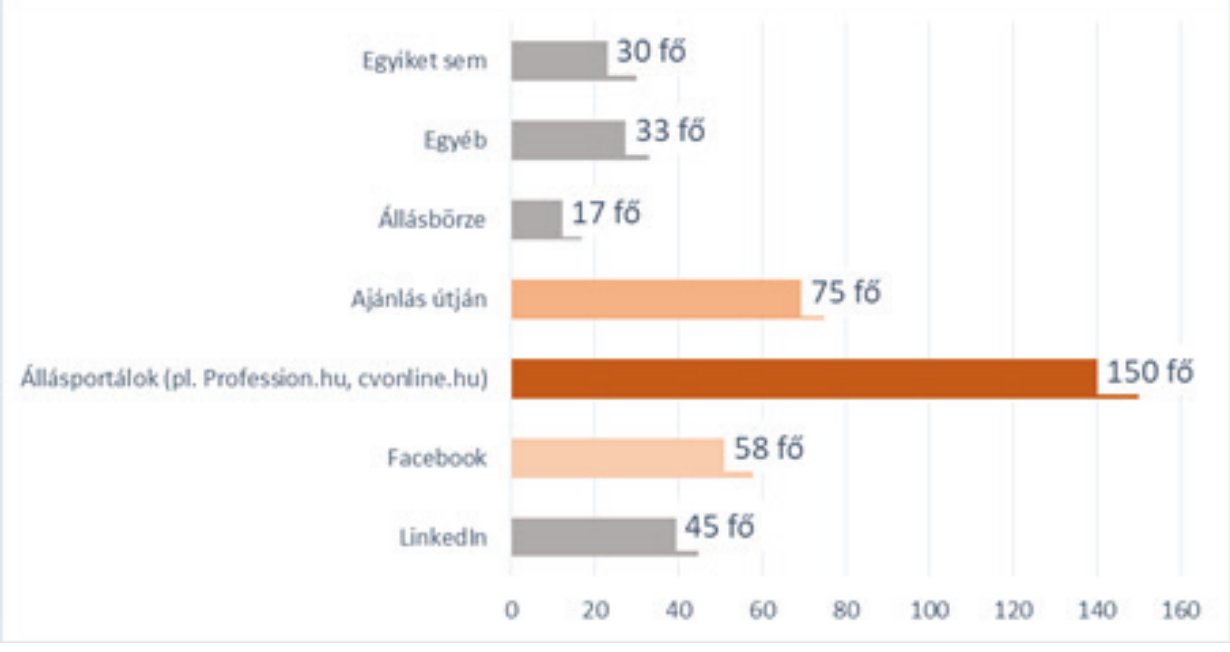

1. ábra: A válaszadók által leggyakrabban használt álláskeresési platformok Forrás: saját szerkesztés, kérdöives megkérdezés alapján, 2019. (n=205)

\section{Munkahelyválasztási döntést befolyásoló tényezök}

A munkavállalók munkahelyválasztási döntését befolyásoló tényezők vizsgálata során egy 9 kérdésből álló kérdéssort állítottunk össze a szakirodalmi áttekintések alapján, 
melyeket a válaszadóknak 1-7-ig terjedő skálán kellett értékelniük. A többváltozós vizsgálatok megkezdése előtt faktoranalízis során redukáltuk a kérdéseket, a vizsgálattal célunk volt, hogy a változók közötti kapcsolatokat feltárjuk.

Mivel a kérdőív skálakérdései előzetes kutatásokra alapozva (Twombly L. A., 2007) kerültek összeállításra, így a primer vizsgálat alkalmával konfirmatorikus jellegű elemzés történt.

A munkavállalók munkahelyválasztási döntését befolyásoló tényezőcsoportok vizsgálatakor a faktoranalízis három faktort azonosított (ld.:1. táblázat), melyek közül:

- $\quad$ az első és egyben a szórást a legmagasabb értékkel magyarázó tényezőcsoport az egyéni készségek, képességek faktor,

- a második az egyéni készségeket, képességeket vállalati oldalról támogató faktor,

- a harmadik a külsö környezeti tényezök faktorok voltak.

\begin{tabular}{|c|c|}
\hline \multicolumn{2}{|l|}{ egyéni készségek, képességek (elsödleges) faktor } \\
\hline - Fontosnak tartom az élethosszig tartó tanulást & 999 \\
\hline - $\quad$ Szeretném tanulmányaimat magasabb szinten folytatni & ,717 \\
\hline $\begin{array}{l}\text { - Fontos számomra, hogy képzettségemnek és szakmai } \\
\text { tapasztalataimnak megfelelő munkám legyen }\end{array}$ &, 221 \\
\hline \multicolumn{2}{|c|}{$\begin{array}{c}\text { egyéni készségeket, képességeket vállalati oldalról támogató } \\
\text { (másodlagos) faktor }\end{array}$} \\
\hline - A vállalatomnál lehetőségem van a karrierem építésére & ,813 \\
\hline $\begin{array}{l}\text { - A vállalatomnál nagy hangsúlyt fektetnek a munkaválla- } \\
\text { lók egyéni készségeinek fejlesztésére }\end{array}$ & ,796 \\
\hline $\begin{array}{l}\text { - Rendszeresen részt veszek a vállalat által támogatott } \\
\text { szakmai képzéseken }\end{array}$ & ,656 \\
\hline \multicolumn{2}{|l|}{ külső környezeti tényezök (harmadlagos) faktor } \\
\hline - Úgy gondolom, könnyü elhelyezkedni a szakmámban & ,627 \\
\hline - Úgy gondolom, nincs okom félteni az állásomat & ,625 \\
\hline $\begin{array}{l}\text { - Úgy gondolom, bérezésem emelkedni fog az elkövetke- } \\
\text { zendő években }\end{array}$ & ,498 \\
\hline
\end{tabular}

1. táblázat: A többváltozós vizsgálat során meghatározott munkahelyválasztási döntést befolyásoló faktorok

Forrás: saját szerkesztés, kérdöives megkérdezés alapján, 2019. (n=205) 
A munkahelyválasztási döntést befolyásoló faktorok kialakítása után a munkavállalók közötti kölcsönös összefüggést kívánta feltárni a kutatás, ezért a továbbiakban klaszteranalízisre került sor, hogy feltárja, vajon a mintában részt vevő munkavállalók homogén csoportokba rendezhetők-e?

A klaszterelemzés három egymástól jól elkülöníthető csoportot azonosított, az egyes klaszterekhez tartozó elemszámok megoszlását a 2. táblázat mutatja.

\begin{tabular}{|c|c|c|c|}
\hline $\begin{array}{c}\text { A klaszterek } \\
\text { sorszáma }\end{array}$ & A klaszterek megnevezése & $\begin{array}{c}\text { A klaszterek } \\
\text { elemszáma }\end{array}$ & $\begin{array}{c}\text { A klaszterek } \\
\text { aránya }\end{array}$ \\
\hline 1. klaszter & $\begin{array}{c}\text { Vállalati támogatást fontosnak } \\
\text { tartók csoportja }\end{array}$ & 89 fó & $43,4 \%$ \\
\hline 2. klaszter & $\begin{array}{c}\text { Egyéni készségek önálló fejlesz- } \\
\text { tését fontosnak tartók csoportja }\end{array}$ & 84 fó & $40,9 \%$ \\
\hline 3. klaszter & Semlegesek csoportja & 32 fö & $15,7 \%$ \\
\hline & Összesen & $\mathbf{2 0 5}$ fó & $\mathbf{1 0 0 , 0} \%$ \\
\hline
\end{tabular}

2. táblázat: A vizsgálat során azonosított klaszterek megoszlása

Forrás: saját szerkesztés, kérdöives megkérdezés alapján 2019. (n=205)

A vizsgálat eredményeit az alábbi diagram ábrázolja (1. ábra).

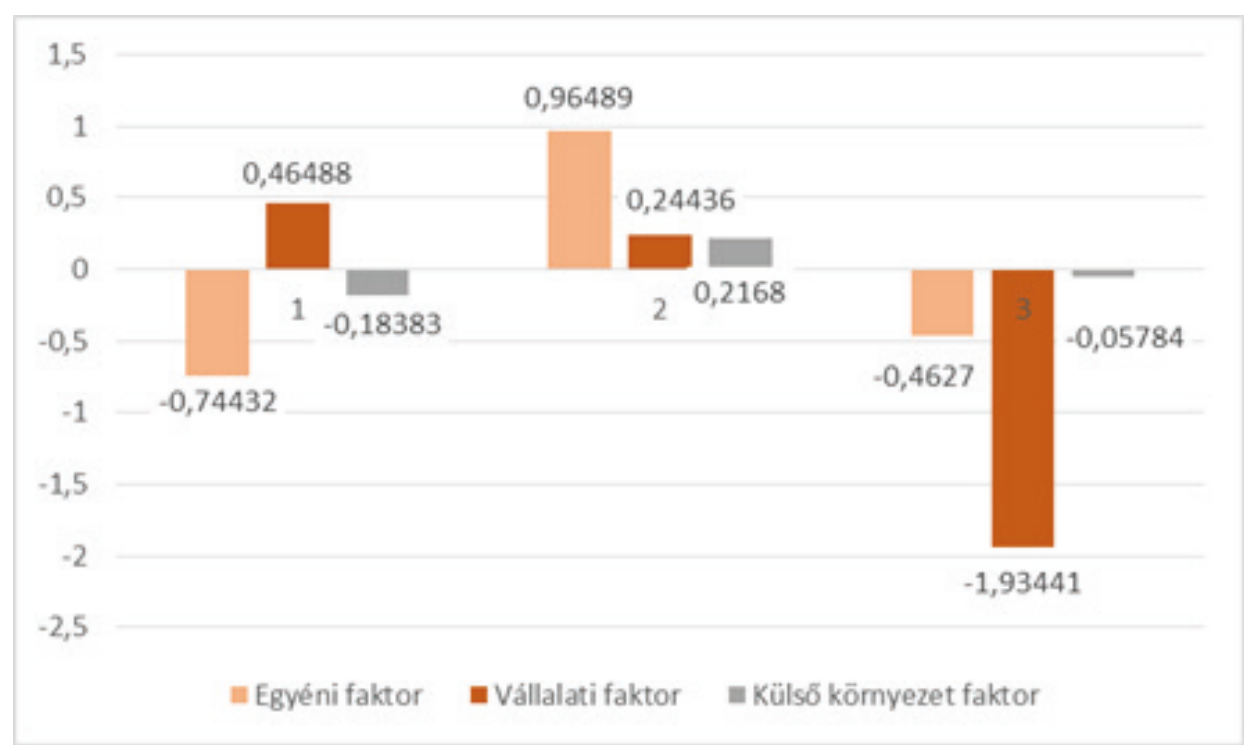

1. ábra: A munkahelyválasztási faktor skálán elért átlagos összpontszámok az egyes klaszterekben (Zscore)

Forrás: saját szerkesztés, kérdöives megkérdezés alapján 2019. (n=205) 
Látható, hogy az első klaszterbe (vállalati támogatást fontosnak tartók csoport) azok a munkavállalók tartoznak, akik számára az egyéni képességeket támogató vállalati tényezők élveznek preferenciát. Ez az eredmény igazolta a H2 hipotézist, mely szerint: Az álláskeresök számára fontosak az egyéni képességeiket támogató vállalati tényezők, vagyis az, hogy a leendő munkáltató megfelelő mértékben járuljon hozzá és támogassa egyéni készségeik, képességeik fejlődését, mert ezen a faktorskálán szerezték a legmagasabb pontokat.

Ezzel szemben a második csoport (egyéni készségek önálló fejlesztését fontosnak tartók csoport), bár valamennyi tényezőt lényegesnek tartja, leginkább a saját, egyéni készségfejlesztésére alapoz, mert ezen a faktoron szerezte a legmagasabb pontokat.

A harmadik klaszter (semleges csoport) tagjai tulajdonképpen egyik tényező fontosságában sem bíznak igazán: legkevésbé a vállalat támogatását tartják elképzelhetőnek, és inkább a külső tényezőket tartják befolyásolónak a munkahelyválasztás során. Választásukat a folyamatosan változó gazdasági, szociális, politikai környezetük változása és adott egyéni élethelyzetük befolyásolja.

Összességében elmondható, hogy valamennyi klaszter kialakításában az „egyéni készségeket, képességeket vállalati oldalról támogató (másodlagos) faktor" volt a legmeghatározóbb, melyet az ANOVA tábla F értéke $(242,356)$ is igazolt $(\mathrm{p}<0,05)$.

\section{Következtetések, javaslatok}

Összességében elmondható, hogy az álláskeresés elsődleges platformja a virtuális tér. Mindemellett a személyes, ismerős általi ajánlás még mindig fontos szerepet tölt be a munkakeresés során Heves megyében, mely elsősorban bizalmi kapcsolatokban jellemző.

A későbbiekben elképzelhető, hogy a nemzetközi trendekhez hasonlóan az online platformok nagy mértékben vagy akár teljes egészében képesek lesznek kiváltani a személyes érintkezést, ideértve - személyzeti tanácsadó cégek esetében - az irodákat is. De jelenleg Heves megyében ez a dominancia még nem észlelhető oly mértékben, mint azt a nemzetközi trendek prognosztizálják. A válaszadók közel felét, a vállalati támogatást fontosnak tartók csoportját a vállalati tényezők befolyásolják elsősorban, elvárásaik vannak a céggel szemben, hogy támogassák a karrierépítésük folyamatát, biztosítsanak lehetőséget a készségeik és képességeik fejlesztéséhez, illetve a szakmai képzéseken való részvételükhöz.

A második munkavállalói szegmens (az egyéni készségek önálló fejlesztését fontosnak tartók csoportja) számára jelentősége van az egyéni képességet támogató vállalati tényezőknek, illetve a külső tényezőknek is, azonban a munkahely megválasztásakor elsősorban azt veszik figyelembe, hogy egyéni képességeiket, készségeiket mennyire tudnák kamatoztatni az adott munkahelyen. 
A harmadik szegmens (a semlegesek csoport) a vállalati tényezőket helyezi előtérbe jelentkezéskor, egyéni készségeik, képességeik másodrangú tényezők csupán. Ők azok a válaszadók, akik már bejártak egy bizonyos karrierutat, szakterületükön szeniornak számítanak, tapasztaltak, és előrelépési lehetőséget keresnek.

A fenti eredmények alapján a következő javaslatokat fogalmaztuk meg:

- A vállalatok fektessenek nagyobb hangsúlyt az employer brandingre, illetve a személyes ajánlási rendszereik kialakítására, mellyel elnyerhetik jövőbeli potenciális munkavállalóik bizalmát, és hatékonyabbnak bizonyulhatnak a piacon a versenytársaknál.

- Szükséges nagyobb hangsúlyt fektetni a passzív álláskeresőkre, ugyanis a megfelelő csatornán hatékony kommunikációs eszközöket felhasználva ők is sikeresen megszólíthatók, aktivizálhatók.

\section{Források}

[1.] Davis, S. (2004): Itt a vég a HR számára? In Effron et al.: HRa 21. században. HVG Kiadó, Budapest.

[2.] Majó Z. (2007): E-HRM: az elektronikus emberi eröforrás menedzsment jelenségvilága - the webolution of HR. Szegedi Tudományegyetem.

[3.] Rose-Ackerman, S. (2001a): Trust and Honesty in Post-Socialist Societies. Kyklos, 54(2-3), pp. 415-443.

[4.] Rose-Ackerman, S. (2001b): Trust, Honesty, and Corruption: Reflection on the State-Building Process. European Journal of Sociology, 42(3), pp. 526570 .

[5.] Rusman, E. (2011): The Mind's Eye on Personal Profiles. How to inform trustworthiness assessments in virtual project teams. Open Universiteit.

[6.] Twombly, L. A. (2017): Factors that Influence Job Choice at the Time of Graduation for Physician Assistants. Seton Hall University.

[7.] Zmerli, S. - Newton, K. (2008): Social trust and attitudes toward democracy. Public Opinion Quarterly, 72(4), 706-724.

[8.] 34. sz. egyezmény a díjat felszámoló munkaerő-közvetítő ügynökségekről. Letöltve: 2019.04.20.

[9.] http://2010-2014.kormany.hu/download/e/89/01000/34E.pdf

[10.] Adó Online, dr. Kártyás Gábor (2015): Kölcsönzés vagy közvetítés? Letöltve: 2019.04 .13$. 
[11.] https://ado.hu/munkaugyek/kolcsonzes-vagy-kozvetites/

[12.] Deloitte, Elemzések (2018): Globális Humán Erőforrás Trendek - 2018. Letöltve: 2019.04.13.

[13.] https://www2.deloitte.com/hu/hu/pages/emberi-eroforras/articles/globalhuman-capital-trends-2018.html

[14.] ELTE Online, Ládonyi Zs. (2015): Mi a helyzet a magyar munkaerőpiacon? - válaszoltak a cégek. Letöltve: 2019.04.14.

[15.] http://elteonline.hu/kozelet/2015/04/13/mi-a-helyzet-a-magyar-munka eropiacon-valaszoltak-a-cegek/

[16.] HR Portal: Íme a legismertebb szolgáltatók a HR piacon. Letöltve: 2019.04.13.

[17.] https://www.hrportal.hu/hr/ime-a-legismertebb-szolgaltatok-a-hr-piacon20100930.html

[18.] Központi Statisztikai Hivatal. Letöltve: 2019.03.31.

[19.] www.ksh.hu

[20.] Milton Konferencia blog. Letöltve: 2015. október 20.

[21.] http://miltonkonferencia.blog.hu/2010/03/01/dimenziovaltas_a_vezetesben

[22.] Munkaügyi Levelek (2003): A kisvállalkozások világa „felfedezésre” vár. Letöltve: 2019.04.14.

[23.] https://munkaugyilevelek.hu/2003/04/szemelyzeti-tanacsadas/

[24.] Portfolio, Veres Dóra (2019): Ez már nem a jövő: van, ahol már robot interjúztatja a jelölteket. Letöltve: 2019.04.20.

[25.] https:/www.portfolio.hu/vallalatok/ez-mar-nem-a-jovo-van-ahol-mar-robotinterjuztatja-a-jelolteket.318397.html 


\section{Szerzők:}

\section{Bata Miléna}

Eszterházy Károly Egyetem, Gyöngyösi Károly Róbert Campus

Vezetés és szervezés MSc (végzés éve: 2019.)

hallgató

batamilena@gmail.com

\section{Benedek Andrea}

Eszterházy Károly Egyetem, Gyöngyösi Károly Róbert Campus

Marketing és Vendéglátás Tanszék

adjunktus

benedek.andrea@uni-eszterhazy.hu 